Uniwersytet Przyrodniczo-

Humanistyczny w Siedlcach

Siedlce University of Natural

Sciences and Humanities

https://bazawiedzy.uph.edu.pl

\begin{tabular}{|l|l|}
\hline Publikacja / Publication & $\begin{array}{l}\text { Principle of evidence of John Amos Comenius as a basis for the development of } \\
\text { pedagogical research techniques and instruments, } \\
\text { Maksimović Jelena, Sretić Sanja }\end{array}$ \\
\hline $\begin{array}{l}\text { Adres publikacji w Repozytorium URL } \\
\text { / Publication address in Repository }\end{array}$ & https://bazawiedzy.uph.edu.pl/info/article/UPH3686dce67a674c85abb0abdcf55f37f7/ \\
\hline $\begin{array}{l}\text { Data opublikowania w Repozytorium / } \\
\text { Deposited in Repository on }\end{array}$ & 22 paź 2021 \\
\hline Rodzaj licencji / Type of licence & Attribution-NoDerivs (CC BY-ND 3.0) \\
\hline & $\begin{array}{l}\text { Maksimović Jelena, Sretić Sanja: Principle of evidence of John Amos Comenius as a } \\
\text { basis for the development of pedagogical research techniques and instruments, } \\
\text { Siedleckie Zeszyty Komeniologiczne seria PEDAGOGIKA, no. 6, 2019, pp. 243- } \\
256\end{array}$ \\
\hline
\end{tabular}


Jelena Maksimović

ORCID: 0000-0001-8356-0211

Sanja Sretić

ORCID: 0000-0001-7019-374X

University of Niš, Serbia

Faculty of Philosophy

\title{
PRINCIPLE OF EVIDENCE OF JOHN AMOS COMENIUS AS A BASIS FOR THE DEVELOPMENT OF PEDAGOGICAL RESEARCH TECHNIQUES AND INSTRUMENTS
}

\author{
DOI: $10.5604 / 01.3001 .0013 .6255$
}

\begin{abstract}
The methodology of pedagogy belongs to the youngest group of pedagogical disciplines. The first thoughts about the basic postulates of the methodology of pedagogy were recognized long ago, even in the pedagogical paradigm of John Amos Comenius (1592-1670), who created support for the methodology of pedagogy as an integral component of pedagogical science. After the presentation of the basic concepts of the pedagogical theory of this Moravian thinker, the principle of evidence in his pedagogical theory is considered in this paper. A review was made of the influence Comenius left on his followers Jean-Jacques Rousseau (1712-1778) and Johann Heinrich Pestalozzi (1746-1827), especially from the point of view of further development of the principles of evidence in their education theories. In this paper, we have confirmed our hypothesis about the compatibility of the principle of evidence with research techniques and instruments. Proactively action by Comenius represents a turning point not only in the field of pedagogy development as a science and its disciplines, but also in the field of human development in general. Regarding that, there is a need for a new pedagogical discipline, Comeniology, which will give a new perspective to this pedagogical doctrine and will foster a critical review in relation to his pedagogical theory. According with our research subject, we have presented some of our dilemmas and questions to which the Comeniology as a new scientific discipline could give an answer, and therefore a kind of scientific contribution. Based on the previous methodological achievements, Comeniology remains committed to discovering the origins of other research techniques and methods in the pedagogical postulates of Comenius, to determine the applicability of the Comenius pedagogical principles with regard to the changes and challenges facing the contemporary teaching process, to open the issue of pedagogical psychological competencies of teachers for the application of the golden rule of Comenius and its other principles, to continue engagement of Comenius in the qualitative educational function of a modern school, but also to consider the influence of other factors (family environment) that may influence the choice of teaching principles and methods.
\end{abstract}

Keywords: John Amos Comenius, principle of evidence, history of pedagogy, methodology of pedagogy, research methods, techniques and instruments, Comeniology 


\section{Introduction}

John Amos Comenius (1592-1670) is one of the greatest pedagogical classics who lived at the transition from the Middle Ages to the new era, a period characterized by wars, poverty, ideological struggles, religious exile, economic inequality. The burdensome social context in which he lived and the tragic family circumstances that followed him throughout his life would be an inspiration for his personal and professional development. With his proactive work and action, Comenius left a strong mark on the development of culture, science and civilization from the earliest times to the modern times. He had a huge impact on the course of history, philosophical thought, social and religious life. For us, most importantly, he is known as the founder of pedagogical science, one of the creators of modern science of education, the initiator of reforms in the field of upbringing and education, the humanist and teacher of the people. His rich creative opus: Informatorium for maternal school (1630); Czech Didactics (1628-1630); Janua lingularum reserata (1631); Sholae pansophica (1650); Didactica Magna (1657); Via Lucis (1668); Orbis sensualium pictus (1654) and many others represent the backbone of the development of numerous pedagogical disciplines, such as didactics, methodology of pedagogy, preschool and school pedagogy, teaching methods. Many progressive, visionary ideas, such as the concept of lifelong learning, have lived many years and even centuries later, which testify not only to the contemporaneity, but also the timelessness of pedagogical creativity of John Amos Comenius.

Using various sources of knowledge in order to find the relevant literature, a large number of foreign and domestic papers of various collections, books, articles, monographs that study the life and work of John Amos Comenius or some of its segments were noticed. Observing available literature, both domestic and international, the impression is that a modest scientific contribution has been given from the aspect of the influence Comenius left on the development of methodology of pedagogy, on the development of research methods, techniques and instruments. Bearing this in mind, there is a responsible task for us to show in the following text the contribution that this Moravian thinker left with his work on the development of the youngest but at the same time for the scientific status the most important pedagogical discipline, methodology of pedagogy. 


\section{John Amos Comenius' reformist movement for the development of pedagogy and its disciplines}

The pedagogical concept of John Amos Comenius is basically theoretical and philosophical, determined by the ideas of humanists, the materialistic philosophy of Francis Bacon and the advanced pedagogical demands of the Renaissance. His rich creative work exudes ancient influence. He respected the ancient tradition considering it as an important part of European identity and the guardian of values that are still useful for modern education (Sitarska, 2015). Many of his followers, including Piaget (Piaget, 1993), believe that Comenius used the language of Aristotle, but gave it a different meaning and content, i.e. he was moving between the scholasticism inspired by Aristotle and the mechanism of natural sciences from the 17th century.

On the basis of his pedagogical doctrine, Comenius sharply criticizes medieval education. He opposes sholastic philosophy to a new philosophy of the unity of the world and the man, and calls it pansophia (pan-all, sophiawisdom), which can be said to have a dual character. The philosophical aspect of pansophia is the universal wisdom, the encyclopedia of knowledge (omnes, omnia, omnino - every, all, perfect) and education and the scientific understanding of the world and life. From the pedagogical point of view, pansophia represents the theory of common education of all people and a unique methodological approach (Vukasović, 1986, Sitarska 2015). It can be said that Comenius, with his ideological views, made a revolution in the way of understanding different areas of reality, first of all a revolution in a different understanding of the process of upbringing and education and laid the foundations for their research.

After completing his formal education, John Amos Comenius begins his reformatory-pedagogical work through school management in many countries throughout Europe. He considered that society could be transformed only if there was a wise and intelligent system of schools in which the entire youth of the nation should be educated (Dobinson, 1970). His pedagogical views bear the seal of the religious understanding of the world, which is directly reflected on the educational goal, "The ultimate goal of man is eternal bliss of God" (Cenić, Petrović, 2005, p. 107). In accordance with his religious ideal, Comenius perceives the man as a manifestation of a detailed divine project. Being a member of the socially-defined religious organization, the "Czech Brethren", which continued the family tradition, Comenius was given a wide democratic character and a basis to his pedagogical theory because it contains 
the demands and interests of the masses (Đorđević, Trnavac, 2007). The primary pedagogical problem for Comenius is rooted in the conviction that every person must go through a process of education that will be based on knowledge of the laws of human nature and represent a means of human cultivation (Dobinson, 1970; Gronts, 2015). Believing that education is a prerequisite for improving the world and a source of power and knowledge, it must not be superficial but profound and fundamental (Pikkarainen, 2012; Lukaš, 2014).

According to the understanding of the process of education, Comenius considered that the school should be in the function of the well-being of the people, and that all knowledge and all scientific achievements belong to all people and all nations who are equal to God (Djordjevic, Trnavac, 2007). The process of upbringing must be in accordance with the nature of man and nature in general, directed at acquiring the highest virtues, such as righteousness, diligence, patience, obedience, humility. In the focus of his science of education is a child, his thoughts and emotions, whose natural abilities should be developed by good upbringing and education (Sitarska, 2015). His childfocused philosophy of education had its full, real meaning experienced many years later, in the period that Elena Kay called the "Child Century".

With his reformist views on the process of upbringing and education, recognizing the need for egalitarianism and the development of education based on the knowledge of the characteristics of children's development, he encouraged in the years that followed numerous research in the field of pedagogical and psychological science. Comenius overcame the time he lived and worked. His mission of enlightening human civilization continued to live in the works of many of his followers to this day.

\section{The principle of evidence in the pedagogical theory of John Amos Comenius}

Pansophia, as an authentic pedagogical philosophy of this Moravian scholar, did not aim exclusively to educate people in an encyclopedic way, but found its immediate application in schools. Namely, Comenius recognized the importance of the practical usefulness of knowledge and the necessity of continuing to confront the theory and practice, thus laying the foundation for the development of a methodological concept in pedagogical science. From the teachers as implementers of the educational process, it is expected not only to transfer knowledge, but to penetrate their thoughts and feelings, understand 
them and participate in their creation (Sitarska, 2015; Maviglia, 2016). In his most important work, The Great Didactic, (Didactica magna, 1657), Komenski opens the issue of teaching principles and methods, thus creating a fertile ground not only for the founding of pedagogy as a science, but for the constitution of its related disciplines, didactics and methodology.

Principle of evidence that is considered to be the forerunner of research techniques and instruments, occurs long before Comenius. Namely, observation and experience as a source of knowledge are found most among the ancient Greek philosophers, Pre-Sockratics among whom Heraclitus stood out for his philosophical thinking, in which philosophical ideas and thoughts appeared not in abstract clarity but as a sensuous image (Uzelac, 2003) and than philosophical views about the importance of sensory experience and obviousness for learning, we also find in the works of Aristotle. Centuries later, the observation as a source of knowledge has been apostrophed and one of the greatest geniuses in the history of Leonardo da Vinci. We can say that Comenius based on the already existing philosophical postulates of his predecessors and under the influence of Francis Bacon and his sensualistic theory of knowledge "that there is nothing in the consciousness that did not go through senses" (Krneta, Potkonjak, 1967) proclamed the principle of evidence the golden rule and explains in detail in his first textbook of apparent teaching "Orbis sensualium pictus" i.e. "The world in pictures" giving him real pedagogical meaning. Many authors (Vukasović, 1986, Sadler, 1970, Lukaš and Munjiza, 2014, Maksimović, Osmanović and Milanović, 2018) recognized that Comenius had established this basic principle of sensory impressions, speech and action. He felt that the inner sensation after setting the objects to be spotted should get the habit of expressing images that emanate from the outer feeling both through the ability of memory, and by hand and tongue. At this stage, the mind can begin to work, and by processes of accurate thought can compare and evaluate all objects of knowledge (Lang, 1965). By nourishing the inductive approach in the process of learning, he emphasized the necessity of linking sensual impressions with the learning of words and activities of students in different areas and in different ways. Senses are the basic and the only source of knowledge, and based on them, by thinking we come to new abstract knowledge. "What the eye can see, the heart believes,... to see and hear in the right way is the first step towards wisdom" (Komenski, 1997).

Regardless of numerous criticisms of the principle of evidence directed at the account of impossibility of its application in any situation and the crea- 
tion of unsuccessful and artificial comparisons, it can be said that by this golden rule, the foundation has been created for the development and application of research methods, techniques and instruments and the fertile ground for the emerging rule of the demonstrative method.

\section{The principle of evidence in the conceptions of pedagogical classics - the impact of John Amos Comenius on Jean Jacques Rousseau and Johann Heinrich Pestalozzi}

The general philosophy of education of John Amos Comenius continued to live and develop further in the pedagogical work of his followers, Jean Jacques Rousseau and Johann Heinrich Pestalozzi, who made great contribution not only to philosophy and pedagogy, but also to the development of its disciplines, primarily the methodology of upbringing and education research, without whose constitution pedagogy would not have the status of a science. In the pedagogical science, Jean Jacques Rousseau (1712-1778) remained known as one of the most important self-taught thinkers of the French enlightenment philosophy, who is said to have performed a Copernican revolution in pedagogy. In his most important pedagogical work "Emile, or on Education" (1762) he presented his revolutionary ideas in the field of education. Johann H. Pestalozzi (1746-1827) is the pedagogical creator of the highest value. Through his pedagogical work and influence, he is known as the father of the poor, the educator of humanity, the teacher of the people. On the basis of pedagogical concepts of his predecessors and their works under whose influence he was, in his most important work, "How Gertrude teaches her children" (1781) he continued the detailed elaboration of the principles of evidence, which enabled him a special place in didactics and methodology of pedagogy.

Understanding the process of upbringing and education of these three pedagogical classics primarily rests on the general principle of the nature of the child and its personality, psychological and developmental characteristics, which is the antipode to medieval education. Thus, Rousseau believes that the educational process should be in line with the development of the child's natural capacities through the process of autonomous discovery (Janković, 2015). The starting point of their conception of education is a sensory experience. Contrary to the mere verbal learning, Comenius, and then Rousseau insist on direct observation. The student must be involved in the learning process, especially through a first-hand experience (Towns, 1975). On the 
basis of his theory of "natural education" that has unlimited power in the periodization of the child's development, Rousseau felt that the senses are intelligence organs that should be developed from the second to the twelfth year of age in the child's life. The base of studying of all subjects in the educational concept of Rousseau is the principle of evidence that requires cooperation of educators and pupils as much as possible (Bazić, 2010). The process of acquiring knowledge during teaching "must be the result of one's own perception and thinking" (Rousseau, 1950: 218). Rousseau's concept of developmental stage and maturing as well as the idea of phylogenesis recapitulation - that a person in individual development repeats the development of the species were the impulse for the beginning of a fertile period, characterized by an empirical approach to the child study, when many biographical studies are developed that deal with the description of the child development in the first years of life (Brković, 2011).

In the spirit of the bourgeois democratic movement and under the influence of German enlightened philosophy, first of all the philosophical conceptual influence of Kant, J.H. Pestalozzi, as the main goal of upbringing, sets the development of natural abilities, i.e. the man's powers so the teaching process should rest on psychophysical abilities of children and development of their independence and humanity. At the core of the teaching process and the process of education is observation that is structured in its character. It begins with observation, after which comes a thinking activity that involves abstraction, generalization, and ultimately thinking... "from vague knowledge to clear concepts" (Cenić, Petrović, 2005; Žlebnik, 1983). In his most important work, "How Gertrude teaches his children," Pestalozzi says: "Only the truth that comes from observation gives man the power which does not let prejudice and delusion penetrate his soul" (Žlebnik, 1983: 108). Observing this pedagogical classic from a methodological perspective, it can be said that it is his significant merit in elaboration of the principles of evidence. Sensory experiences have the axiological value as they represent a means for the development of reason and judgment. Educated senses are a prerequisite for creating clear ideas about the reality that surrounds us (Towns, 1975). 


\section{The principle of evidence of John Amos Comenius as the basis for the development of research techniques and instruments in the methodology of pedagogy}

Pedagogical views of Comenius on the process of teaching are characterized by cognitive realism that is applied not only to the field of obvious and inductive teaching, but also to the area of methodology of pedagogical research. For the first time in the history of development of pedagogical science, Comenius tried to find a methodology that could contribute to the full development of the human character (Maviglia, 2016). It can be said that this begins to create contours of pedagogy as an independent science and methodology of pedagogy as a new pedagogical discipline. Progresive and revolutionary ideas of this Moravian scholar and whole galaxy of educators and members of other sciences (J.H. Pestalozzi, J.J. Rousseau, the philosophical concept of Immanuel Kant etc.) facilitated the work of Johann Friedrich Herbart during the 19th century who is merit for systematization ie. constitution of an autonomous and complete scientific system of pedagogy relying on two firm foundations, philosophy (ethics) and psychology (Đorđević, Trnavac, 2007).

Pedagogy, analogously to its related sciences must satisfy scientificstatus criteria, that is, except epistemological dimensions, it should possess the adequate methodology of scientific research by which the collected knowledge fund will be systematized into a scientific system. Although the development of methodology of pedagogy has started quite late, only in the second half of the 20th century, it is today a safe stronghold for scientific and research work in pedagogical science. Progressive development and improvement of techniques and instruments for empirical research have been particularly recognized, thus overcoming the weaknesses of so-called deductive and normative pedagogy (Maksimović, Petrović, 2012; Maksimović, Osmanović, 2017). Pedagogical science abounds with numerous methods of discovering scientific reality. Each of them (the method of theoretical analysis, the historical method, the genetic/development method, the system-structural functional method, the modeling method, the experimental method, the ex-post facto method and the descriptive method) apply different methods, techniques of research work in order to achieve the set goal in the planned and systematic way, but also appropriate tools and instruments that get to scientifically-based facts. 
The pedagogical doctrine and the nature of the principle of evidence of Comenius and his followers, represent the precursor to the development and application of research pedagogical techniques and instruments. The descriptive, empirical research method lies at the heart of research observation technique. It provides a thorough introduction of a phenomenon because it is oriented towards the acquisition of a description of phenomena and relationships among them (Knežević-Florić, Ninković, 2012) and can be an introduction for other research. It is recognized that the research technique of observation rests on the principle of evidence. Precisely because of its roots drawn from Comenius' golden rule, the observation technique is considered one of the oldest research techniques. It is based on the activation of senses and the sensualist dimension of the observer. Observation that is applied in order to improve existing scientific pedagogical knowledge is an organized, systematic and worthwhile observation (Krneta, Potkonjak, 1967; Potkonjak, Banđur, 1999). The Golden Rule of John Amos Comenius in the pedagogical work of his followers was interpreted from the aspect of its versatility. Hence, the requirement for the versatility of the research observation techniques, which confirms the scientific character of the obtained observation results. This research technique can explore those phenomena that are accessible to senses and have external manifestation. The observation process is compatible with the inductive approach in the process of learning in Comenius' pedagogical theory and his followers. While the process of acquiring knowledge moves from sensory experiences through thought to abstract concepts, the process of observation begins by noticing and perceiving through the rapid and objective registration of the observed to changing and improving educational practice as the highest goal of observation.

The basis of the systemic observation that Mužić $(1968 ; 1999)$ proposes as the most direct and most natural way of getting to know the phenomena in the process of education is found in direct observation that Comenius, and especially Rousseau, not only fought against scholasticism, but also saw the possibility of observing the phenomena as they really were. By observing the principle of evidence and the observation technique, we notice another very important analogy. The principle of evidence requires the activation of students through the engagement of their senses while the technique of observation requires the active, conscious and systematic participation of observers in the activities, interests and emotions of the group that is watching. The observation process can also occur through the form of selfobservation, i.e. introspection wich we also find in filosofical refelctions 
of Heraclitus (Uzelac, 2003), wich Comenius further elaborates and tranfers to a concrete level. This is sometimes the only way to examine the phenomenon in the personality of students, teachers and other participants in the teaching process. Complexity and dinamism of the phenomena that are obrserved in the contemporary teaching process make observation still inevitable on the path of learning and registering pedagogical reality and is a prerequisite for improving educational practice. For this purpose, it uses numerous, versatile tools, i.e. instruments (list of observations, anecdotes, observation diaries, interviews, surveys, scaling) with the aim of collecting data and processing them in a quantitative or qualitative manner.

Regardless of the great value and significance of the principle of evidence, the basis of the observation technique, one should bear in mind that the principle of evidence is not the only principle in the teaching process and that we cannot master all knowledge only by its application. Thus, neither by observation techniques can be solved or learned all questions of pedagogical practice. And as the teaching process combines several teaching principles, in that way in the process of studying one pedagogical phenomenon or problem, multiple research methods and techniques should be combined.

\section{Concluding remarks}

The analysis of the used domestic and foreign literature of historical, pedagogical and methodological character leads us to the conclusion that John Amos Comenius is the most magnificent figure at the individual, scientific and social level. His unwavering belief in the human development of a man and equally strong belief that education can improve the world are timeless and generally important ideas. With his analytical approach in relation to the current social context and the educational system as its microsystem, he managed to reform the previous concept of a man, the process of education, the organization of school work and life. Looking through the prism of a pedagogical science, his merits are numerous. In addition to his democratically oriented efforts to reform schooling, by which he is widely known, in the pedagogical work of Comenius, we find ideas for constitution of some pedagogical disciplines, such as the methodology of pedagogy which has acquired its scientific status for many years and centuries later. We find the roots of the research of the process of upbringing and education in his principles that make up the content of his most important work, "Didactica Magna". Therefore, he is rightly regarded as an experimenter and innovator in various fields 
of scientific research. Considering his crucial contribution to the development of pedagogy as a science and methodology of pedagogical research as its constitutive discipline, and his revolutionary and visionary ideas of a permanent continuous process of education, we recognize that Comenius will still continue to be a subject of scientific research. Every pedagogical discipline observes Comenius from the aspect of his contribution to the subject of studying a certain discipline, but we are under the impression that there is a lack of a holistic approach to his personal and professional work. Is this the time when there is a need for the constitution of a new pedagogical discipline, Comeniology, which will, through cultivating interdisciplinary and multidisciplinary approach, substitute the disadvantages of the related disciplines and see this Moravian thinker in a new light?

As with every pedagogical discipline, Comeniology is expected to use the achievements in the field of methodology of pedagogical research, existing research methods, techniques and instruments whose foundations are found in the postulates of the pedagogical theory of Comenius. It can be said that the unity of his educational enterprise rests on a kind of methodology that we could rightly call Comenian. Our theoretical research work confirmed our hypothesis that the nature of the principle of the obviousness guides the founding and development of research techniques and instruments. In other words, there exists the compatibility of the principle of evidence and observation techniques. This entails thinking that one of the tasks of the new scientific discipline could actually be the discovery of the origins of other research methods and techniques from the pedagogical postulates of Comenius, which would have double scientific significance both for the development of Comeniology and for the development of methodology of pedagogy.

The unlimited power of the principle of evidence in the pedagogical theory of Comenius and his followers from this time distance is actually a utopian vision of Christian human society, which is mostly governed by virtues and the unilateral, perhaps even superficial understanding of the process of learning and gaining scientific knowledge. We would agree that perceptual experiences are basic but not the only source of knowledge, since the knowledge gained only through the senses is short-lived, especially when it comes to younger children. Observing the aspect of periodization of the development of the children which Piaget and Vygotsky studied later, the period of abstract thinking is only present in the higher grades of elementary school and in that sense, we cannot expect perceptual experiences to directly lead to abstract concepts how Comenius had postulated. Guided by the needs 
and the best interest of those whom we educate, we need to investigate the application of this principle on the contemporary teaching process and its effects on the process of acquiring knowledge in students. It also seems that Comenius and his followers have neglected the influence of the family environment as the first social environment from which the child comes and the family experiences with which the children come to school and which may influence the choice of a particular teaching method or principle. The teacher, as an extended hand of parents, has a crucial role in the process of educating their students. In the light of the increasingly demanding and responsible role of teachers, in the context of complex interpersonal, and first and foremost, family relationships that reflect on pupils, and thus on the school itself, there is the dilemma if a modern teacher is familiar with the nature of the principle of obviousness and if he or she possesses pedagogically-psychological competencies for applying this as well as other teaching principles and methods? From the period of Comenius to the present day, we are struggling with the didactic intellectualism which seems to have taken the primacy of the educational function of the school. What further increases the need for it to rise on a qualitatively higher level is that even today more than ever the school becomes the only place of education for young generations. Does the rich pedagogic inheritance left behind by Comenius and his followers can be of significance on the path of forming a versatile personality?

With this work, we have stated our dilemmas and with numerous questions opened a discussion about the problems that obstruct the educational practice, some of which are still known from the Comenius period. We expect Comeniology to use many research techniques and methods to answer our questions but also to initiate changes that will enable the achievement of the set educational goals.

\section{Bibliography}

Banđur Veljko, Potkonjak Nikola, Metodologija pedagogije, Beograd 1999.

Bazić Mirjana, Komparativna analiza koncepcija intelektualnog vaspitanja Džona Loka i Žan-Žaka Rusoa. Rad je nastao u okviru projekta Duhovne pojave i stvaralaštvo srpskog naroda na Kosovu i Metohiji od XV do XX veka, Miinistarstva nauke Republike Srbije 2010.

Brković Aleksa, Razvojna psihologija, Čačak 2011.

Cenić Stojan, Petrović Jelena, Vaspitanje kroz istorijske epohe, Vranje 2005.

Dobinson Charles Henry, Comenius and contemporary education, Hamburg 1970. 
Đorđević Jovan, Trnavac Nikola, Pedagogija, Beograd 2007.

Grontsova Iolana, The social-pedagogical thinking of J. A Comenius, „Educational Sciences", 2015, no 7(3), p. 16-21.

Knežević-Florić Olivera, Ninković Stefan, Horizonti istraživanja u obrazovanju, Novi Sad 2012.

Komenski Jan Amos, Velika didaktika, Beograd 1997.

Krneta Ljubomir, Potkonjak Milena, Potkonjak Nikola, Pedagogija. Beograd 1967.

Lang Irene, A Comparative Study of the Philosophies of John Amos Comenius and Maria Montessori on the Education of Children. 1965 Preuzeto 25.05.2019. god. sa sajta: https://ecommons.luc.edu/cgi/viewcontent. cgi?article=1774\&context=luc_diss.

Lukaš Mirko, Munjiza Emerik, Education System of John Amos Comenius and its Implications in Modern Didactics, „Život i škola: časopis za teoriju i praksu odgoja i obrazovanja“,2014, no 60(31), p. 32-42.

Janković Ivana, Obrazovanje i (deliberativna) demokratija. Ovaj rad je nastao u okviru projekta "Logičko-epistemološki osnovi nauke i metafizike" Ministarstva prosvete, nauke i tehnološkog razvoja Republike Srbije 2015.

Maksimović Jelena, Osmanović Jelena, Pedagoški rad Jana Amosa Komenskog sa osvrtom na princip povezanosti teorije i prakse u metodologiji pedagogije, In: B. Sitarska (ed.), Współczesne recepcje Jana Amosa Komeńskiego, „Siedleckie Zeszyty Komeniologiczne, seria pedagogika”, vol. IV, Siedlce 2017, p. 327-336.

Maksimović Jelena, Osmanović Jelena, Milanović Aleksandra, Značaj Jana Amosa Komenskog za razvoj metodologije pedagogije, „Siedleckie Zeszyty Komeniologiczne, seria pedagogika", vol. V, Jan Amos Komeński $w$ epoce współczesności. Odczytania - kontynuacje - krytyka, Siedlce 2018, p. 105-119.

Maksimović Jelena, Petrović Jelena, Razvoj metodologije pedagogije u Srba, „Istraživanja u pedagogiji“, 2012, no 56(34), p. 151-161.

Maviglia Domenica, The Main Principles of Modern Pedagogy in 'Didactica Magna' of John Amos Comenius. "Creative Approaches to Research", 2016, no 9(1), p. 57.

Mužić Vladmir, Metodologija pedagoškog istraživanja, Sarajevo 1968.

Mužić Vladimir, Uvod u metodologiju istraživanja odgoja i obrazovanja, Zagreb 1999.

Piaget Jean, Jan Amos Comenius, „Prospects“, 1993, no 23 (1-2), p. 173-196.

Pikkarainen Eetu, Signs of Realit. In Theories of Bildung and Growth (p. 19-29). Sense Publishers, Rotterdam 2012. Preuzeto 28.05.2019 god sa sajta: https://link.springer.com/chapter/10.1007/978-94-6209-031-6_2. 
Ruso Žan Žak, Emili ili o vaspitanju, Beograd 1950.

Sitarska Barbara, John Amos Comenius and the beginnings of comeniology, In: B. Sitarska (ed.), Jan Amos Komeński - jego pedagogika i filozofia, „Siedleckie Zeszyty Komeniologiczne, seria pedagogika”, vol. II, Siedlce 2015, p. 45-65.

Vukasović Ante, Utjecaj Jana Amosa Komenskog na pedagoška i kulturna stremljenja u Hrvatskoj, „Prilozi za istraživanje hrvatske filozofske baštine“, 1986, no 12 (1-2), p. 163-175.

Towns Leon Elmer „A History of Religious Educators", Books. Paper 24, 1976.

Uzelac Milan, Istorija filozofije I (Istorija filozofije do Dekarta), Vršac 2003.

Žlebnik Leon, Opšta istorija školstva i pedagoških ideja, Beograd 1983. 